\title{
CD30-dependent degradation of TRAF2: implications for negative regulation of TRAF signaling and the control of cell sunvival
}

\author{
Colin S. Duckett ${ }^{1}$ and Craig B. Thompson ${ }^{2}$ \\ Howard Hughes M edical Institute, Gwen Knapp Center for Lupus and Immunology Research, and Department of M edicine, \\ The University of Chicago, Chicago, Illinois 60637 USA
}

CD30 is a cell-surface receptor that can augment lymphocyte activation and survival through its ability to induce the transcription factor NF-kB. CD30, however, has also been implicated in the induction of apoptotic cell death of lymphocytes. Here we show that one of the effects of CD30 signal transduction is to render cells sensitive to apoptosis induced by the type 1 tumor necrosis factor receptor (TNFR1). This sensitization is dependent on the TRAF-binding sites within the CD30 cytoplasmic domain. One of the proteins that binds to these sites is TRAF2, a signal transduction molecule that is also utilized by TNFR1 to mediate the activation of several downstream kinases and transcription factors. During CD30 signal transduction, we found that binding of TRAF2 to the cytoplasmic domain of CD30 results in the rapid depletion of TRAF2 and the associated protein TRAF1 by proteolysis. These data suggest a model in which CD30 limits its own ability to transduce cell survival signals through signal-coupled depletion of TRAF2. Depletion of intracellular TRAF2 and its coassociated proteins also increased the sensitivity of the cell to undergoing apoptosis during activation of death-inducing receptors such as TNFR1. Consistent with this hypothesis, expression of a dominant-negative form of TRAF2 was found to potentiate TNFR1-mediated death. These studies provide a potential mechanism through which CD30, as well as other TRAF-binding members of the TNFR superfamily, can negatively regulate cell survival.

[Key Words: Apoptosis; N F-кB; CD30; TRAF; TN F; proteases]

Received July 7, 1997; revised version accepted August 27, 1997.

An essential feature of the immune system is the ability to tolerate large fluctuations in cell number. Homeostasis is thought to be achieved through the integration of intracellular and extracellular signals that function to balance the degree of cell proliferation with the rate of cell death (Oltvai and Korsmeyer 1994; Allison and Krummel 1995). Lymphocyte activation and proliferation is initiated by the engagement of antigen with its clonotypic cell-surface receptor (Weiss and Littman 1994). Additional costimulatory signals, however, are also required. For example, costimulatory signal s can be mediated in T cells by signaling through the CD28 receptor (Allison and Krummel 1995) and in B cells through the CD40 receptor, a member of the tumor necrosis factor/nerve growth factor (TNF/NGF) receptor superfamily (Choi et al. 1995).

The TNF/NGF receptor superfamily is a group of re-

\footnotetext{
${ }^{1}$ Present address: Metabolism Branch, National Cancer Institute, $\mathrm{Na}$ tional Institutes of Health, Bethesda, MD 20892.

${ }^{2}$ Corresponding author.

E-MAIL Craig@Knapp.uchicago.edu; FAX (773) 702-1576.
}

lated cell-surface receptors that include the types 1 and 2 TNF receptors (TNFR1 and TNFR2), Fas, CD27, 4-1BB, and CD30 (Vassalli 1992; Armitage 1994; Beyaert and Fiers 1994; Gruss and Dower 1995). Many of these re ceptors have been found to play costimulatory roles in cell proliferation, whereas others have been shown to induce apoptosis. Interestingly, several members of this family, such as TN FR2 (Tartagl ia et al. 1993; Zheng et al. 1995), CD40 (Foy et al. 1996; Rathmell et al. 1996), and CD30 (see below), have been shown to play dual roles, although the mechanism(s) underlying this apparent ambiguity is unknown. To understand this phenomenon, we have examined the signaling properties of one of these receptors, CD30.

CD30 is a lymphoid cell-restricted receptor (Dürkop et al. 1992) that is normally expressed on activated and memory T cells (Ellis et al. 1993). CD30 was originally identified on the surface of Hodgkin's Iymphoma cells (Schwab et al. 1982; Stein et al. 1985b; Falini et al . 1995), and high levels of CD 30 expression have also been found to correl ate with disease progression in anaplastic large cell Iymphoma (N adali et al. 1995). Signal transduction 
through CD30 has been found to augment T-cell receptor-mediated proliferation under some circumstances (Smith et al. 1993), but in other cases to potentiate apoptosis (Lee et al. 1996). A ctivation of CD30 has al so been shown to stimulate HIV expression (Maggi et al. 1995), probably through its ability to activate the transcription factor N F-кB (Siebenlist et al. 1994; Biswas et al. 1995). Targeted disruption of the murine CD30 gene, however, has implicated CD30 in thymic negative selection (Amakawa et al. 1996).

The signaling properties of T NFR-rel ated receptors are being rapidly elucidated. Several TNF receptor family members, including Fas, TNFR1, and DR3/Wsl/Apo-3, have been found to contain an $~ 80$-residue motif designated the death domain (T artaglia et al. 1993; Takahashi et al. 1994; Chinnaiyan et al. 1996; Kitson et al. 1996; Marsters et al. 1996; Pan et al. 1997), and signaling through these receptors has been shown to induce apoptosis in a manner that is dependent on dimerization of the death domain of the receptor with similar death domains of cytoplasmic factors such as FADD, TRADD, and RIP (Chinnai yan et al. 1995; Hsu et al . 1995; Stanger et al. 1995). In contrast, the cytoplasmic domains of a number of other TNF receptor family members, including TNFR2 and CD40, have been shown to interact with members of the recently described TNF receptor-associated factor (TRAF) family of signaling molecules (Baker and Reddy 1996). We and others have recently identified TRAF1, TRAF2, TRAF3, and TRAF5 as factors that can be recruited to the cytoplasmic domain of CD30 and have shown that these molecules play central roles in signal transduction through this receptor (Ansi eau et al. 1996; Gedrich et al. 1996; Lee et al. 1996; Aizawa et al. 1997; Duckett et al. 1997; Tsitsikov et al. 1997).

Six mammal ian TRAF proteins have been identified to date (Baker and Reddy 1996). These factors have been shown to possess distinct affinities for different members of the TNF receptor superfamily. The TRAF proteins have been suggested to be important in promoting cell survival because of their role in promoting NF-kB activation through receptors of the TNF receptor family (Beg and Baltimore 1996; Liu et al. 1996; Van Antwerp et al. 1996; Wang et al. 1996). In addition, animals with a targeted TRAF3 disruption (Xu et al. 1996) and transgenic mice expressing TRAF1 (Speiser et al. 1997) have both been reported to display defects in lymphocyte development and survival.

In this report we describe a mechanism by which signaling through CD30 can both promote initial cell survival while at the same time setting in motion a signaling-dependent mechanism to leave the cell subsequently more susceptible to apoptosis through death domaincontaining receptors. The ability of CD30 to promote cell survival is dependent on its ability to recruit a TRAF-dependent signal transduction complex (Duckett et al. 1997). Now, we show that the recruitment of TRAF2 into this complex results in the signal-coupled depletion of TRAF2 and its coassociated signaling molecule TRAF1. This depletion in TRAF2 correlates with increased cellular sensitivity to cell death in response to
TNFR1 signal transduction. This phenomenon is not unique to CD 30 signal transduction, but also occurs following TNFR2 signal transduction. Consistent with the central role of the TRAF2 signaling complex in modulating the apoptotic sensitivity of cells in response to TNFR1 engagement, dominant-negative TRAF2 was found to directly mimic the ability of CD30 signal transduction to sensitize cells to TNFR1-induced apoptosis.

\section{Results}

CD30 signaling potentiates TNFR1-mediated apoptosis

Recent papers have shown an important role for N F-кB activation in the regulation of cell survival (Beg and Baltimore 1996; Liu et al. 1996; Van Antwerp et al. 1996; Wang et al. 1996), and we have shown that CD30 is a potent activator of N F-кB (Duckett et al. 1997). The human embryonic kidney cell line 293 previously has been shown to express TN FR 1 but not TN FR2 (Liu et al. 1996; C.S. Duckett and C.B. Thompson, unpubl.). 293 cells were transfected with expression vectors encoding green fluorescent protein (GFP) as a marker of transfection, together with a plasmid encoding a chimeric protein comprised of the cytoplasmic domain of CD30 fused to the extracellular and transmembrane domains of CD28. This chimeric protein is expressed on the cell surface as a constitutive homodimer, and this dimerization is sufficient to initiate CD30 signal transduction in a ligandindependent manner (Duckett et al . 1997). Expression of this protein on the cell surface results in potent N F-кB activation. In contrast, a CD28 deletion mutant lacking a cytoplasmic domain (CD28 $\Delta$ Tail) has no effect on N F$\kappa B$ activation (Duckett et al. 1997). The present experiments were initiated to determine whether CD30 signal transduction could inhibit the ability of death domaincontaining proteins such as TN FR 1 from inducing apoptosis. In our initial experiments, cells were stimulated with recombinant TN F- $\alpha 12 \mathrm{hr}$ after transfection and subsequently evaluated for viability by nuclear staining with 4',6'-diamidino-2-phenylindole (DAPI) and fluorescence microscopy. Contrary to our expectations, TN F- $\alpha$ had no effect on the viability of parental 293 cells or the cells transfected with the tailless CD28 construct. In contrast, $70 \%$ of the CD 30 transfectants died in response to $18 \mathrm{hr}$ of TNF- $\alpha$ treatment (Fig. 1A). The nuclear condensation and morphological changes as observed by DAPI staining and analysis by fluorescence microscopy were indicative of apoptosis (data not shown). This cell death was dependent on TN F- $\alpha$, as the CD 30 chimera in the absence of TNF- $\alpha$ had no significant effect on viability. Flow cytometric analysis of cells transfected with the CD28-CD30 and the CD28 4 Tail vectors surface expression revealed very similar levels of CD28 surface expression (data not shown).

Previous work has shown that CD30 signal transduction is dependent on a TRAF-binding region located within the carboxy-terminal 36 amino acids of the cytoplasmic domain (Duckett et al. 1997). To determine the role of the TRAF-binding domain of CD30 in the poten- 
Figure 1. Potentiation of TNFR1-mediated cell death by constitutively activated chimeric CD30. (A) 293 cells were transfected with a vector (100 ng) encoding GFP together with expression vectors $(1 \mu \mathrm{g})$ encoding a fusion between CD28 and CD30, a mutated CD28-CD30 vector lacking the carboxy-terminal TRAF-binding sites ( $\Delta$ Traf), or a control CD28 mutant lacking a cytoplasmic tail $(\Delta T$ ail $)$, as indicated. Twelve hours following transfection, cells were stimulated with human TN F- $\alpha(200 \mathrm{U} / \mathrm{ml})$ or a medium control for a further $24 \mathrm{hr}$, and viability of GFP-expressing cells was determined by fluorescence microscopy as described in Materials and Methods. (B) CD30-enhanced death is blocked by apoptosis inhibitors. 293 cells were transfected either with the CD28 $\Delta$ T ail control vector (Control) or with the CD28-CD30 chimera (CD30), together with the indicated expression vectors. Transfectants were stimulated with recombinant TN F- $\alpha$ and viability determined as described above and in Materials and M ethods.

tiation of TNF- $\alpha$-induced death, we examined the ability of a mutant of CD28-CD30 chimera that lacks the TRAF-binding motifs ( $\Delta$ T raf) to potentiate TN F- $\alpha$-mediated death. In contrast to the vector containing the fulllength CD30 tail, this mutant was unable to induce the sensitivity to TN F- $\alpha$ (Fig. 1A). Thus, contrary to our expectations, these data suggest that CD 30 can potentiate TN F-medi ated apoptosis. This potentiation is dependent on the TRAF-binding sites in CD30.

To characterize the mechanism of cell death induced by the combination of CD30 signaling and TNF- $\alpha$, expression vectors were cotransfected encoding viral proteins that are known to block apoptotic cell death induced by members of the caspase family of cysteine proteases. Expression of either the baculoviral apoptotic inhibitor, P35 (Clem et al. 1991; Bump et al. 1995), or the cowpox virus inhibitor, CrmA (Gagliardini et al. 1994; Komiyama et al. 1994), completely abrogated the cell death induced by TNF- $\alpha$ plus CD30 signaling (Fig. 1B), indicating the involvement of caspases and confirming that the cell death was caused by apoptosis.

\section{TRAF2 is degraded upon recruitment to CD30}

The experiments described above suggested a role for the TRAF proteins in the potentiation of TNFR1-mediated death. Because TRAF2 has also been found to be involved in TNFR1-mediated signaling (Hsu et al. 1996), we sought to characterize cellular TRAF2. Endogenous TRAF2 protein in 293 cells was not detectable by immunobl ot analysis with commercial ly avail able TRAF2-specific antibodies (Fig. 2A; data not shown), indicating that TRAF2 is normally expressed at levels below the threshold of detection in this cell type. Therefore, a mammalian expression vector encoding human TRAF2 was transfected into 293 cells together with either the chimeric CD28 vector containing the CD30 cytoplasmic tail, or the CD28 vector lacking a cytoplasmic tail. Surprisingly, whereas TRAF2 protein was easily detected in
Iysates from cells cotransfected with the TRAF2 plus control CD28 tailless vectors, TRAF2 was virtually undetectable when cotransfected with the CD28-CD30 chimera (Fig. 2A). This effect was not observed when TRAF2 was coexpressed with a CD 30 vector lacking the TRAF-binding domains. High levels of TRAF2 protein were also detected when the TRAF2 vector was transfected alone or with a variety of additional control vectors (data not shown).

To investigate why we failed to detect TRAF2 protein in cells transfected with TRAF2 in the presence of the

A

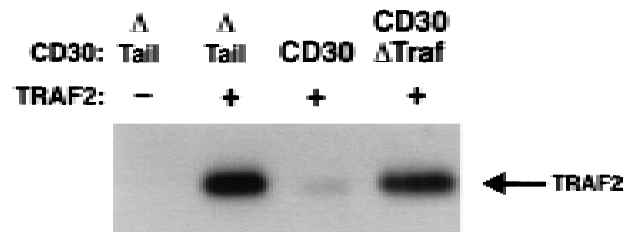

B

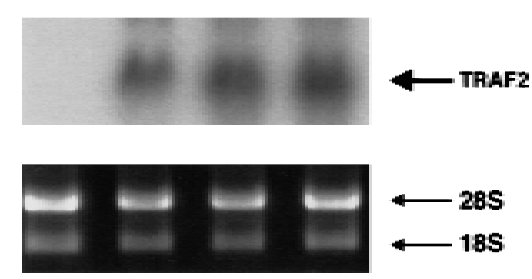

Figure 2. TRAF2 is destabilized by CD30. 293 cells were cotransfected with TRAF2 and CD28 chimera expression vectors as indicated. (A) Cells were lysed $18 \mathrm{hr}$ following transfection, standardized for protein levels, and TRAF2 levels were detected by immunobl ot analysis as described in $M$ aterials and $M$ ethods. (B) Total RN A was prepared from an equivalent aliquot of cells used for A, and TRAF2 mRNA was evaluated by Northern analysis with a TRAF2 cDNA probe. (Bottom) An ethidium bromide-stained agarose gel to standardize the RNA samples; (top) an autoradiograph of the TRAF2-probed blot. 
chimeric CD28-CD30 receptor, the levels of TRAF2 RNA were examined by Northern analysis. The amounts of TRAF2 RN A were similar in cells cotransfected with

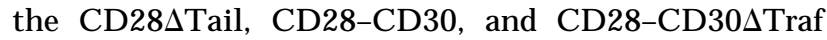
vectors (Fig. 2B). These data suggest that TRAF2 is being transcribed at equival ent rates in the presence or absence of the CD28-CD30 receptor. The failure of TRAF2 protein to accumulate appears to be mediated by post-transcriptional mechanisms.

CD30-induced destabilization of TRAF2 can be blocked by protease inhibitors

To further characterize the process of CD30-induced TRAF2 destabilization, a panel of protease inhibitors were tested for their ability to inhibit CD30-induced TRAF2 degradation (Fig. 3). Lactacystin, a specific inhibitor of the ubiquitin-proteasome pathway (Krappmann et al. 1996), was unable to rescue the degradation of TRAF2 (Fig. 3), although a number of less specific compounds such as E64 and TLCK were able to inhibit TRAF2 degradation. In addition, several inhibitors of the cal pain family of cysteine proteases were found to efficiently block CD30-induced TRAF2 degradation. The cal pains are a family of cytoplasmic, cal cium-activated cysteine proteases that have been implicated in the induction of apoptosis (Squier and Cohen 1997). These data suggest that the binding of TRAF2 to the cytoplasmic tail of CD30 activates a protease or proteases that result in the degradation of TRAF2.

Heteromeric complexes containing TRAF2 are also degraded upon recruitment to CD30

It has previously been shown that TRAF1, TRAF2, and TRAF3 can be directly recruited to the cytoplasmic domain of CD 30 (Ansi eau et al. 1996; Gedrich et al. 1996; Lee et al. 1996). M ore recently, three additional members of the TRAF family have also been identified, TRAF4, TRAF5, and TRAF6 (Tomasetto et al. 1995; Cao et al.

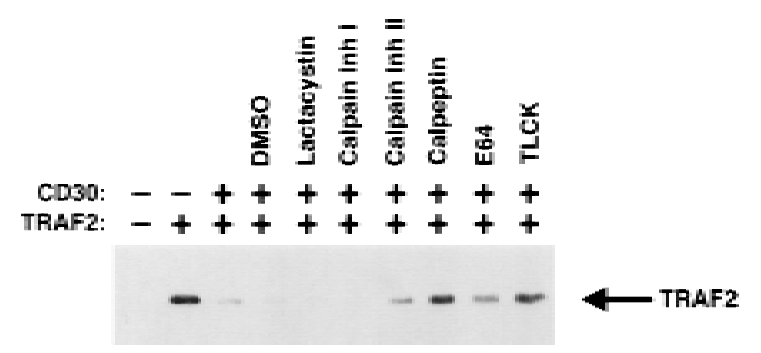

Figure 3. TRAF2 destabilization can be blocked by protease inhibitors. 293 cells were transfected with TRAF2 and chimeric CD28-CD30 expression vectors as indicated. Parallel wells were stimulated $36 \mathrm{hr}$ foll owing transfection with the indicated protease inhibitors each at a final concentration of $50 \mu \mathrm{m}$ or with a DMSO solvent control at a final concentration of $0.001 \%$, and lysates were prepared $48 \mathrm{hr}$ after transfection. Standardized extracts were examined for TRAF2 by immunoblot analysis as described in Materials and Methods.
Table 1. Comparison of the ability of CD 30 to bind the six known TRAF proteins with its degradative properties

\begin{tabular}{lcc}
\hline & Binding to CD30 & Degradation by CD30 \\
\hline TRAF1 & ++ & - \\
TRAF2 & ++ & ++ \\
TRAF3 & ++ & + \\
TRAF4 & - & - \\
TRAF5 & ++ & + \\
TRAF6 & - & -
\end{tabular}

The $\mathrm{Cd} 30$ binding column has been amal gamated from current published data (Ansieau et al. 1996; Gedrich et al. 1996; Lee et al. 1996) and unpublished data. The degradation by CD30 column summarizes the data obtained by coexpression of CD28CD30 chimeras with expression vectors encoding wild-type TRAF1, TRAF2, or TRAF3, with Myc epitope-tagged TRAF4 and TRAF5, or with FLAG epitope-tagged TRAF6, followed by immunoblot analysis, as indicated. (+H) The respective TRAF protein was reduced $>80 \%$ by coexpression with the CD 30 chimera, as determined by immunoblot analysis, (+) a reduction of $50 \%$ or less; $(\rightarrow$ no change.

1996; Ishida et al . 1996a,b; N akano et al . 1996; A izawa et al. 1997). Therefore, the six known TRAF proteins were assessed for their abilities to be degraded upon CD30 signaling (Table 1). Interestingly, TRAF2, TRAF3, and TRAF5 were degraded, presumably upon binding to CD30, whereas the levels of TRAF1, TRAF4, and TRAF6 were not evidently affected by coexpression of CD30 (Table 1). TRAF1 is able to bind to the CD 30 tail, but was not degraded, suggesting that additional determinants may be present in TRAFs 2,3 , and 5 which confer binding-specific degradation.

As shown in Table 1, TRAF1 was not degraded by CD30 signal transduction. Because TRAF1 and TRAF2 can form heterodimers (Rothe et al. 1994, 1995b), we tested the possibility that TRAF1 might function to stabilize TRAF2. Expression vectors encoding TRAF1 and TRAF2 were cotransfected into 293 cells together with either the CD28-CD 30 vector or the control vector lacking a cytoplasmic tail. Cotransfection of TRAF1 had no stabilizing effect on TRAF2 (Fig. 4A). In fact, whereas expression of TRAF1 alone was not affected by the presence of CD30, coexpression of TRAF1 with TRAF2 resulted in the al most complete disappearance of TRAF1, suggesting that recruitment by TRAF2 of TRAF1 into a heteromeric complex with CD 30 resulted in degradation of both TRAF proteins.

The RING finger of TRAF2 is required for CD30-mediated degradation

Both TRAF1 and TRAF2 possess similar characteristics of recruitment to the two TRAF-binding sites in CD30 (Gedrich et al. 1996), but as shown in Figure 4A, TRAF1 was not degraded directly by CD30 signal transduction. The principal structural difference between TRAF1 and TRAF2 is the presence of a RING finger domain in TRAF2. Therefore, the properties of a mutant version of 


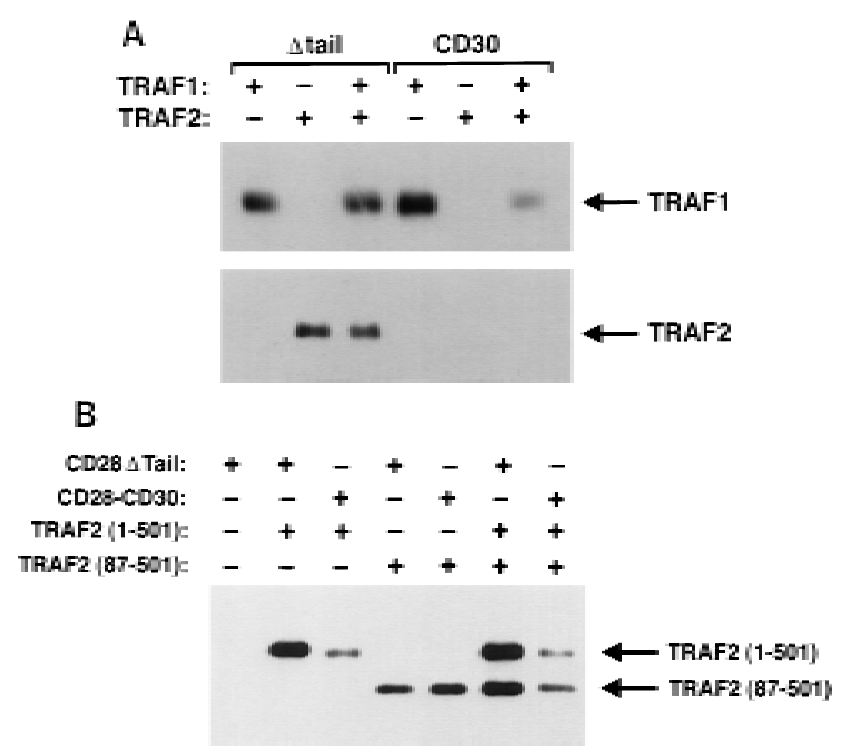

Figure 4. Determinants of TRAF degradation. (A) 293 cells were transfected with expression vectors encoding the indicated proteins. Lysates were prepared $48 \mathrm{hr}$ following transfection and standardized aliquots were subjected to immunoblot analysis with a polyclonal antibody to TRAF1 (top) or TRAF2 (bottom). (B) 293 cells were transfected with the indicated plasmids, including either wild-type TRAF2 (1-501) or a dominant-negative mutant (87-501) lacking a functional RIN G finger, as indicated. Cells were prepared $24 \mathrm{hr}$ foll owing transfection and analyzed as described in A with a TRAF2 polyclonal antibody.

TRAF2 that lacks the RIN G finger domain were examined. Deletion of the amino-terminal 86 residues of TRAF2 has previously been reported to disrupt the RIN G finger domain of TRAF2 without diminishing its ability to bind to CD30 (Gedrich et al. 1996). This mutant, TRAF2 (87-501), functions in a dominant-negative manner to inhibit CD30-mediated signaling (Duckett et al. 1997). As shown in Figure 4B, TRAF2 (87-501) was not degraded by coexpression with CD 30 , whereas in control transfections, the level of full-length TRAF2 was dramatically reduced. These findings suggest that the amino terminus of TRAF2, which contains a RIN G finger, is required for degradation foll owing recruitment to the cytoplasmic tail of CD30.

Previous studies have shown that TRAF2 is able to form homodimers, as well as heterodimers with TRAF1 (Rothe et al. 1995b). Because TRAF1 was degraded when coexpressed with TRAF2 and CD30, we reasoned that the dominant-negative TRAF2 (87-501), which is not degraded when coexpressed with CD30 (Fig. 4B), might become subject to degradation if coexpressed with fulllength TRAF2. As shown in Figure 4B, levels of cotransfected full-length TRAF2 and truncated TRAF2 (87-501) were dramatically reduced on coexpression with the CD 28-CD 30 chimera. This suggests that a complex containing both the full-length and the truncated (87-501) forms of TRAF2 is degraded upon recruitment to CD30.
Both TRAF-binding sites in CD 30 contribute to TRAF degradation

Previously we have shown that TRAF2 can bind independently to ei ther of two 5-7 residue elements in CD 30 (domains $2 \mathrm{~A}$ and $2 \mathrm{~B}$ ), and that each of these elements are independently capable of recruiting TRAF proteins and inducing N F-KB activation (Gedrich et al. 1996; Duckett et al. 1997). Therefore, additional mutants of the CD30 cytoplasmic tail were tested to determine which of the two TRA F-binding elements was required to produce destabilization of TRAF2. The TRAF2 expression vector was cotransfected into 293 cells together with chimeric CD30 variants lacking the TRAF-binding domain $2 \mathrm{~A}$ only, 2B only, or both $2 \mathrm{~A}$ and $2 \mathrm{~B}$. Individual disruption of either TRAF-binding domain $2 \mathrm{~A}$ or $2 \mathrm{~B}$ resulted in mutants that induced intermediate levels of TRAF2 degradation (Fig. 5). In control transfections, wild-type CD30 resulted in the almost complete loss of TRAF2. These data suggest that whereas either TRAF-binding site is capable of partially destabilizing TRAF2, both sites are required for maximal destabilization.

\section{TNFR2 can also enhance TNFR1 sensitivity and} induce TRAF2 degradation

To determine whether the ability to heighten sensitivity to TNFR1 signals and to induce the degradation of TRAF2 is a unique property of CD30 or is shared by other TNF receptor family members, we examined the properties of TN FR2. A chimeric vector was constructed encoding the cytoplasmic domain of TN FR2 fused to the extracellular and transmembrane domains of CD28. Transfection of this vector into 293 cells resulted in comparable levels of both surface CD28 expression and $\mathrm{N} F-\kappa \mathrm{B}$ induction to those observed after transfection of the CD28-CD30 chimera or the control CD284tail vector (data not shown). Similar to the results found with the CD28-CD30 protein, cells transfected with the CD28-TNFR2 chimera were al so sensitized to TNFR1-

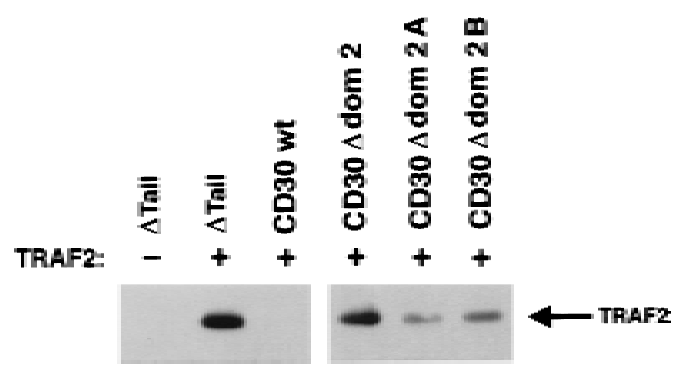

Figure 5. Both TRAF-binding sites in CD30 contribute to TRAF degradation. 293 cells were cotransfected with TRAF2 and CD28 chimera expression vectors encoding wild-type CD30, tailless CD28 ( $\Delta$ Tail), or mutated proteins lacking both TRAF-binding motifs ( $\Delta$ dom 2 ) or each of the individual TRAFbinding domains ( $\Delta$ dom $2 \mathrm{~A}$ or $\Delta$ dom $2 \mathrm{~B}$ ), as indicated. Cells were lysed $18 \mathrm{hr}$ following transfection and standardized for protein levels, and TRAF2 levels were detected by immunobl ot analysis as described in $\mathrm{M}$ aterials and $\mathrm{M}$ ethods. 


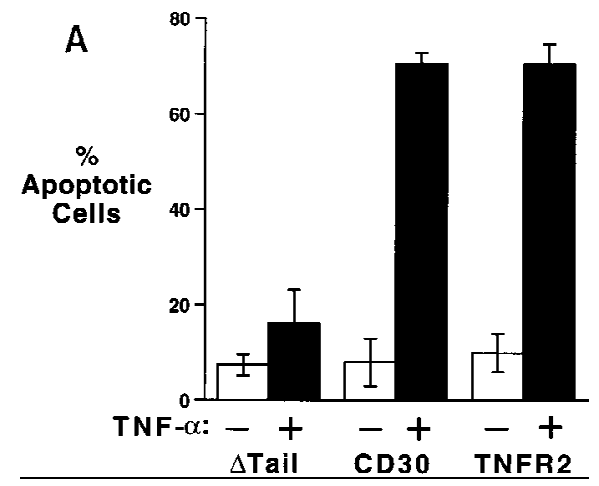

mediated death. The degree of sensitization was almost identical to that found for the CD28-CD30 chimera (Fig. 6A). In addition, cotransfection of CD28-TNFR2 with TRAF2 also induced the degradation of TRAF2 (Fig. 6B), reveal ing that the enhancement of TNFR1 sensitivity, as well as the TRAF2 degradation following recruitment to the receptor, is not restricted to CD30, but can occur with other members of the TN F receptor superfamily.

\section{Blockade of TRAF2 signaling can potentiate}

\section{TNFR 1-mediated death}

The experiments described above show that the recruitment of TRAF2 to CD 30 results in its destabilization by a mechanism that involves proteolysis. Activation of TNFR1 has also been shown to effect the recruitment of TRAF2 to the TNFR1 cytoplasmic tail, by virtue of a TNFR1-TRADD-TRAF2 interaction (Hsu et al. 1996), and this recruitment has been implicated in the activation of downstream signals, notably NF-кB (Rothe et al. 1995b) and JN K (N atoli et al. 1997) activation. One consequence of TRAF2 degradation by CD30 might be to inhibit TRAF-mediated signaling by TN FR 1 . T o test this possibility, 293 cells were transfected with the dominant-negative TRAF2 (87-501) vector, treated with either recombinant TNF- $\alpha$ or a media control for $24 \mathrm{hr}$, and assayed for viability. As shown in Figure 7, similar to the effect of the constitutively active CD30 chimera, expression of dominant-negative TRAF2 greatly sensitized the cells TNF- $\alpha$-mediated death, suggesting that blocking the ability of TRAF proteins to participate in TNFR1dependent signal transduction can enhance the sensitivity to TNF- $\alpha$.

CD30 signaling abrogates the induction of NF-кB by $\mathrm{TNF}-\alpha$

Previous studies have found that the induction of N F-kB can confer protection from TNF- $\alpha$-mediated death (Beg and Baltimore 1996; Liu et al. 1996; Van A ntwerp et al. 1996; Wang et al. 1996). Because TRAF2 has been reported to play an integral role in the activation of N F-кB by TNFRI (Hsu et al. 1996), the ability of cells to respond to TNF- $\alpha$ following prol onged CD30 signal transduction was examined. Cells were transfected with the chimeric CD28-CD30 plasmid or with the tailless control plasmid. Forty-eight hours later, cells were stimulated with TNF- $\alpha$ and then eval uated for N F-кB levels by luciferase reporter gene assays. Cells transfected with the CD28CD30 plasmid were unable to induce NF-кB in response to TNF- $\alpha$ treatment (Fig. 8), whereas cells transfected with the control plasmid induced NF-кB-dependent reporter gene activity in response to TNF- $\alpha$.

\section{Discussion}

A subfamily of TNF receptor superfamily members has recently been defined that shares the common ability to

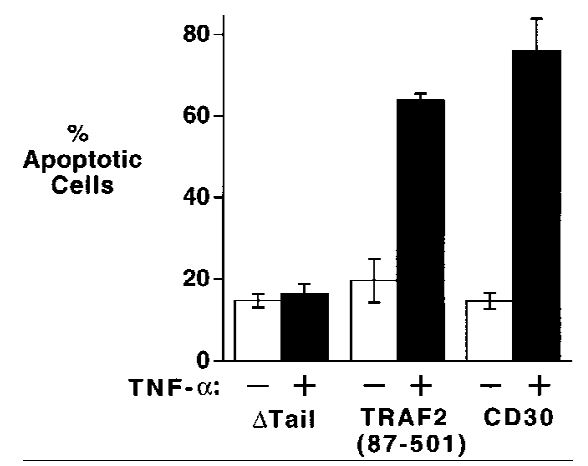

Figure 7. Dominant-negative TRAF2 can potentiate TNFR1mediated death. 293 cells were transfected with 100 ng of GFP plasmid, together with $1 \mu \mathrm{g}$ of the indicated plasmids, and either mock treated or treated with human TN F- $\alpha(200 \mathrm{U} / \mathrm{ml})$, and cell viability was determined as described in the legend to Fig. 1 and in $M$ aterials and M ethods. 


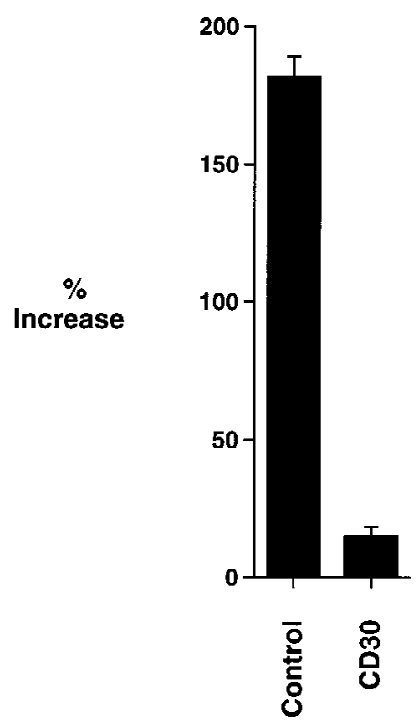

Figure 8. CD 30 signal ing abrogates N F-kB induction by TNF-

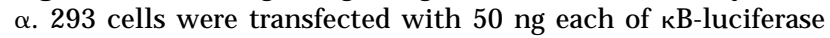
reporter plasmid and $\beta$-gal actosi dase plasmid, al ong with $100 \mathrm{ng}$ of either CD28-CD 30 vector or tailless CD28 as indicated. Cells were stimulated with TN F- $\alpha 48 \mathrm{hr}$ following transfection, and incubated further for $10 \mathrm{hr}$ prior to harvest. The induction of $\mathrm{NF}-\mathrm{\kappa} B$ is presented as the percentage increase in N F-кB of T N F$\alpha$-treated samples over the activity of the reporter plasmid in mock-treated cells. Luciferase assays were performed as described in Materials and M ethods.

initiate signal transduction through TRAF proteins, leading to the induction of NF-кB. In most cases, this promotes cell survival. These same receptors, however, have been implicated in cell death, under some circumstances. UnlikeTN FR 1, Fas and DR3/Wsl / A po-3 (Tartaglia et al. 1993; Takahashi et al. 1994; Chinnaiyan et al. 1996; Kitson et al. 1996; Marsters et al. 1996; Pan et al. 1997), which contain death domains capable of inducing apoptosis through the recruitment and activation of caspases ( $\mathrm{N}$ agata 1996), it is not known how these receptors can induce apoptosis.

As an example, CD30 appears to play dual roles in the cell. CD30 has been reported to promote the development and differentiation of $T$ helper type 2 (Th2) cells (Del Prete et al. 1995), and, therefore, has been associated with cellular survival and proliferation. In contrast, other findings have implicated CD30 in the activation of cell death (Lee et al. 1996). Disruption of murine CD30 by homologous recombination (A makawa et al. 1996) has implicated a role for this receptor in thymic negative selection.

Similar to CD 30, TN FR2 has been shown to exert both pro-survival and pro-death effects on the cell. TNFR2 can confer protection from cell death, and cellular proliferation (Rothe et al. 1994). In contrast, TNFR2 has been reported to play a role in apoptosis of mature T cells (Zheng et al. 1995). Several models have been proposed to account for the opposing properties of TNFR2. The rapid association/dissociation kinetics of TNFR2 for its ligand have led to the ligand passing hypothesis (Tartaglia et al. 1993), in which TN FR2 is postulated to recruit TNF- $\alpha$ and provide a source of ligand for TNFR1, thus suggesting a passive role for TNFR2 in signaling. Grell and coworkers have suggested that TNFR2 specifically binds membrane-associated TN F- $\alpha$ and thereby induces cell death (Grell et al. 1995), al though this does not necessarily exclude the ligand-passing model. More re cently, it has been shown that the cytoplasmic domain of TNFR2 is required for the potentiation of TNFR1mediated death (Weiss et al. 1997), suggesting that cooperative signaling through these receptors, perhaps by ligand-induced oligomerization, may play a role in this cooperative response.

The experiments described here may provide an explanation for the dual effects of CD30 and TNFR2. Stimulation of 293 cells with TNF- $\alpha$ alone did not induce a significant degree of cell death (Fig. 1). Although 293 cells contain the product of the antiapoptotic adenovirus gene E1B 19K, which may function to raise the cellular apoptotic threshold, constitutive signal transduction mediated either by a CD28-CD30 or a CD28-TNFR2 chimera potentiated TN FR 1-induced cell death (Figs. 1A and 6A). The TRAF-binding domain in CD30 was required for potentiation (Fig. 1A), and other reports have shown that the TRAF-binding element in TNFR2 is required for sensitization by this receptor (Weiss et al. 1997). This suggests that CD30 signaling functions by the same mechanism as TNFR2 to potentiate TNFR1mediated death. Because CD 30 and TN FR2 are normally activated by independent ligands, this raises the possibility that other members of the TN F receptor superfamily that utilize the TRAF signaling pathway may also function to potentiate TN FR 1-mediated death by a simiIar mechanism. It is formally possible that the apoptotic properties of CD30 and TN FR2 are mediated by recruitment and activation of caspases, for example, through the formation of a TRAF2-TRADD-FADD-caspase complex. Because CD 30 was unable to induce cell death in the absence of a TNFR1 signal, however, it is more likely that CD30 functions as a cofactor to potentiate the cytotoxic effects of TNFR1.

As shown in Figure 2A, we found that TRAF2 protein was al most completely degraded by activation of CD30mediated, TRAF-dependent signals. This destabilization did not occur at the transcriptional level (Fig. 2B), but could be inhibited by several protease inhibitors (Fig. 3), suggesting the involvement of a proteolytic program that specifically degrades TRAF2.

Degradation of TRAF2 could be induced by recruitment to either of the two TRAF-binding domains in CD30 (Fig. 5) that have previously been identified (Gedrich et al. 1996). Degradation could also be induced by recruitment to TNFR2 (Fig. 6B), suggesting a shared pathway. Signal transduction mediated by CD30 and TNFR2 utilizes TRAF2, which subsequently leads to $N F-\kappa B$ activation. This activation has been previously shown to involve the degradation of $I_{\kappa} B$ by the ubiquitin-proteasome pathway (Palombella et al. 1994; Chen et al. 1995, 1996; Henkel et al. 1995; DiDonato et al. 1996; 
Hateboer et al. 1996). Signaling through endogenous TNFR1, however, which also results in the TRAF2-mediated activation of N F-kB (H su et al . 1996) and induces the degradation of IкB (Chen et al . 1995; DiDonato et al. 1995; Henkel et al. 1995), did not result in the destabilization of TRAF2 (Fig. 6B). Although it is possible that ectopically expressed, activated TNFR1 might also induce TRAF2 degradation, these findings suggest that the determinants of TRAF2 degradation are distinct from those of I $\mathrm{KB}$ degradation.

Signal ing through CD30 does not induce a general degradation of all TRAF proteins (Table 1). Moreover, binding of TRAF proteins to CD 30 is not sufficient to induce degradation, because TRAF1 binds directly to CD30 (Gedrich et al . 1996) but is not degraded. One difference that may account for this is the absence of a RING finger domain in TRAF1. As shown in Figure 4B, the di sruption of the RING finger of TRAF2 abrogated degradation, suggesting that the RIN G finger of TRAF2 may play a role in destabilization. Interestingly, the RING finger has also been reported to be required for NF-кB activation by TRAF2 (Rothe et al. 1995b), suggesting that the RING finger may be required both for protein-protein interactions with downstream signaling components as well as for the targeting of TRAF2 for degradation. Thus, the TRAF2 (87-501) mutant is not subject to degradation and so might block N F-kB activation by competitively binding to CD30, thereby preventing recruitment of endogenous TRAF2 to CD 30. The construction of fusion proteins between TRAF1 and TRAF2, however, have so far failed to generate a chimeric TRAF1-TRAF2 molecule that could be degraded by CD30 signaling (C.S. Duckett and C.B. Thompson, unpubl.), suggesting that additional determinants in TRAF2 may also be required. Also noteworthy is the observation that TRAFI can be degraded when coexpressed with TRAF2. This finding suggests that the degradation of TRAF2 can extend to additional molecules associated with TRAF2, and this might also be the case for factors unrel ated to the TRAFs such as the C-IAPs, TAN K/I-TRAF, Nik, A20 and TRIP, all of which have been shown to associate directly with TRAF2 (Rothe et al. 1995a, 1996; Cheng and Baltimore 1996; Song et al. 1996; Lee et al. 1997; Malinin et al. 1997).

TRAF2 is a signaling intermediate that is also utilized by TNFR1 (Hsu et al. 1996). Whereas TRAF2 can bind directly to the cytoplasmic domains of TNFR2 and CD30, it is recruited indirectly to TNFR1 through a TNFR1-TRADD-TRAF2 interaction (Hsu et al. 1996), where it is thought to mediate NF-кB activation. Several groups have reported that N F-кB induction can confer antiapoptotic properties on the cell (Beg and Baltimore 1996; Van Antwerp et al. 1996; Wang et al. 1996). Expression of a dominant-negative mutant of TRAF2, which blocks NF-кB induction by TNFR1, potentiated TNFR1-mediated death (Fig. 7). Therefore, the inhibition of TRAF2-induced signaling, either by expression of a dominant-negative TRAF2 or by the CD30-induced degradation of TRAF2, can sensitize cells to TNFR1-mediated death. Consistent with this hypothesis, CD30 signal transduction and concomitant TRAF2 degradation abrogated the ability of TN F- $\alpha$ to induce N F-кB (Fig. 8). A further prediction of this model is that the treatment of cells with protease inhibitors that can block TRAF2 degradation might confer protection to death induced by TNFR1 plus CD30 signal transduction. Preliminary studies suggest that this is the case (C.S. Duckett and C.B. Thompson, unpubl.). The compounds that inhibit TRAF2 degradation, however, al so cross-react with the ubiquitin-proteasome pathway and have been shown to block NF-кB induction by TNF- $\alpha$, and the combined treatment of TNF- $\alpha$ plus protease inhibitors was found to be toxic to the untransfected and control transfected populations of cells (C.S. Duckett and C.B. Thompson, unpubl.).

These studies describe a mechanism by which members of the tumor necrosis receptor superfamily may cooperate to modulate cell survival. The recruitment of TRAF2 to the cytoplasmic tails of CD30 or to TNFR2 is followed by its degradation. There are at least two consequences of this event. First, the removal of TRAF2 would be predicted to limit the duration of the receptorinduced signal, thus ensuring that the signal is self regulating. Second, several TN FR2-associated proteins, such as TRAF2 and the c-IAPs, have been found to possess antiapoptotic properties (Liston et al. 1996; Liu et al. 1996; Uren et al. 1996), and because TRAF2-associated proteins were al so found to be degraded by CD30, elimination of these factors might be predicted to sensitize the cell to additional signals such as those mediated by TNFR1 (Fig. 9). The observation that CD30 and TNFR2 signaling can sensitize cells to death in the context of TNFR1 signals might al so explain how signaling through CD30 or through TNFR2 can induce disparate effects ranging from cellular prol iferation to apoptosis (Smith et al. 1993; Stein et al. 1985a,b). The removal of TRAF2 by degradation might therefore be expected to interfere with the induction by TNFR1 of antiapoptotic signals, resulting in a shift to the remaining TRADD-FADDcaspase pathway (Fig. 9).

Theinduction of proteolytic degradation of TRAF2 following recruitment to CD30 and TNFR2 will result in the termination of signal transduction through these receptors. Foll owing decay of the N F-кB-mediated survival signal, cells will be subsequently more susceptible to dying if activated by death domain-containing receptors such as TNFR1, unless TRAF2 and its coassociated signaling mol ecules can be regenerated during this interval. Factors that increase the expression of these proteins are, therefore, likely to help maintain the duration of survival signaling through CD30 and TNFR2. These data suggest that the rate of receptor-mediated TRAF2 consumption and TRAF2 translation are likely to play a dynamic role in the regulation of cell survival.

\section{Materials and methods}

Plasmids

The chimeric CD28-CD30 vectors, the $\Delta$ tail control plasmid, and the expression vectors encoding TRAF1, TRAF2, and 


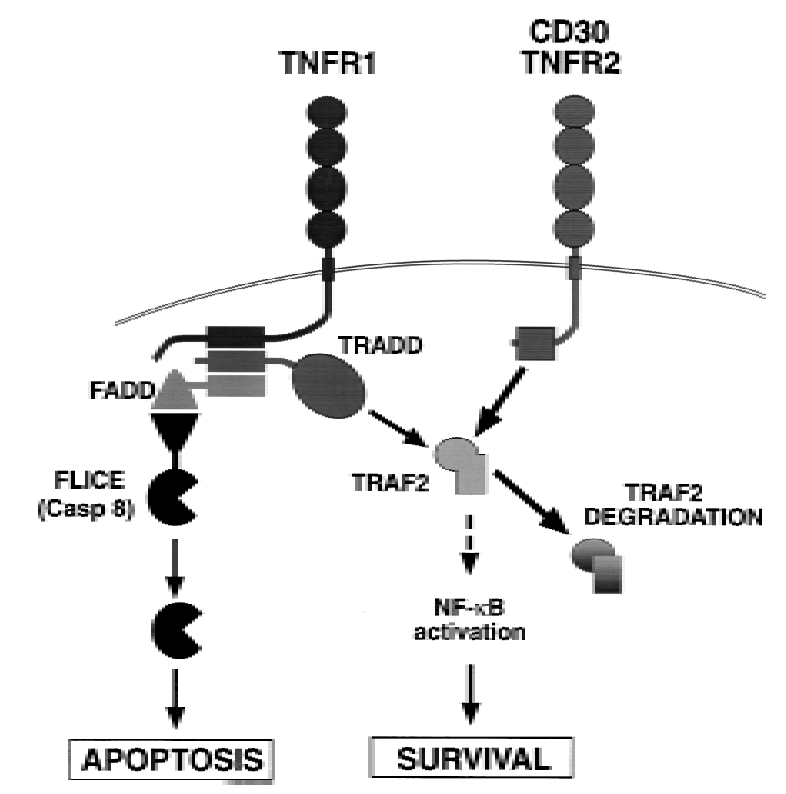

Figure 9. Model: Control of TRAF2 levels may modulate the sensitivity of cells to TNFR1 signals (see text for details).

TRAF3 have been described previously (Duckett et al. 1997). The $\Delta$ T raf vector encodes the CD 28 extracel lular domain fused to residues $410-531$ of CD30, a deletion that previously has been shown to abrogate TRAF binding (Gedrich et al. 1996; Duckett et al. 1997). The CD28-TNFR2 chimera was constructed by PCR amplification of the TNFR2 cytoplasmic tail from a human T-cell cDN A library with the following primers: 5'-ATACTCGAGACAGGTGAAAAAGAAGCCCTTGTGCC$3^{\prime}$ and 5'-AATTCTAGACCACCTTGGCTACGACACAGCCCAC-3'. The PCR product was subcloned in-frame into the modified CD 28 expression vector described previously (Duckett et al. 1997). The GFP expression vector was obtained from Clontech laboratories. The Myc epitope-tagged human TRAF4/ CART 1 expression vector was kindly provided by $C$. Rudin and J. Van Dongen (both at University of Chicago, IL). The murine TRAF5 vector was kindly provided by R. Arch (University of Chicago, IL); the amino terminus was modified to incorporate the Myc epitope tag (Duckett et al. 1996) prior to subcloning into the pcDNA3 mammalian expression vector (Invitrogen). Human TRAF6 was obtained by PCR amplification from a human T-cell cDNA library followed by subcloning into the pFLAG-CM V-2 expression vector (Kodak).

\section{Cells and transfections}

Human embryonic kidney 293 cells were maintained in Dulbecco's modified Eagle's medium (DMEM) with $10 \%$ fetal bovine serum, $2 \mathrm{~mm}$ glutamine, $100 \mathrm{U} / \mathrm{ml}$ of penicillin and 100 $\mu \mathrm{g} / \mathrm{ml}$ of streptomycin, and grown at $37^{\circ} \mathrm{C}$ in $5 \% \mathrm{CO}_{2}$. Six-well plates were seeded with $2 \times 10^{5}$ cells per well in $2 \mathrm{ml}$ of me dium. The medium was replaced the following day, and cells were transfected by the calcium phosphate procedure as described previously (Duckett et al. 1997).

Viability assays

Cells were cotransfected with $100 \mathrm{ng}$ of GFP plasmid and $1 \mu \mathrm{g}$ of CD28 chimeric plasmid as indicated in the text. Unless stated otherwise, the medium was removed $12 \mathrm{hr}$ post-transfection and replaced either with fresh medium containing human recombinant TNF- $\alpha$ (Boehringer Mannheim) at $200 \mathrm{U} / \mathrm{ml}$ or with medium alone, and cells were maintained for a further 18 to $24 \mathrm{hr}$ as indicated, before harvest. M edium from transfected cells was collected, cells were washed once with phosphate buffered saline (PBS) supplemented with $1 \mathrm{~mm}$ ethylenediaminetetraacetic acid (EDTA), and cells were detached from the plate in the same buffer. Cells, washes, and medium were pooled, and cells were pelleted by centrifugation at $1500 \mathrm{rpm}$ at $4^{\circ} \mathrm{C}$. Pellets were washed once in PBS/EDTA and fixed in PBS containing $1.25 \%$ glutaraldehyde $(1 \mathrm{ml})$. Fixed cells were washed once with PBS, resuspended in $1 \mathrm{ml}$ PBS containing $4^{\prime}, 6^{\prime}$-diamidino-2-phenylindole (DAPI) at $20 \mathrm{ng} / \mathrm{ml}$, and incubated for $10 \mathrm{~min}$ at room temperature. Stained cells were washed once in PBS and resuspended in $1 \mathrm{ml}$ PBS. Aliquots (typically $50 \mu \mathrm{l}$ ) were spun onto microscope slides with a Cytopro cytocentrifuge (Wescor), and cells were examined by fluorescence microscopy by use of a Leitz DM-RB microscope.

\section{Analysis of TRAF protein levels}

Cells were cotransfected with $100 \mathrm{ng}$ of the indicated CD28 chimeric vector and $1 \mu \mathrm{g}$ of TRAF expression vector. Lysates were prepared $12-48 \mathrm{hr}$ after transfection as indicated in the figure legends, as follows: Cells were washed once in PBS and lysed in $0.5 \mathrm{ml}$ of lysis buffer [ $25 \mathrm{~mm}$ HEPES at pH 7.9, $100 \mathrm{~mm}$ $\mathrm{NaCl}, 1 \mathrm{~mm}$ EDTA, 1\% Triton $\mathrm{X}-100,10 \%$ glycerol, $1 \mathrm{~mm}$ dithiothreitol, $0.1 \mathrm{~mm}$ phenylmethanesulfonyl fluoride, and a cocktail of protease inhibitors (Boehringer $M$ annheim)]. Protein levels were standardized with the Bradford reagent (Bio-Rad). Samples were electrophoresed on 9.5\% SDS-polyacrylamide gels and immunoblotted with commercial rabbit polyclonal antibodies to human TRAF1, TRAF2, or TRAF3 (Santa Cruz Biotechnologies), or with murine monoclonal antibodies to the Myc epitope (Pharmingen; clone 9E10) or FLAG (Kodak; M 2) as indicated in the text. Blots were subsequently probed with horseradish peroxidase-conjugated anti-rabbit or anti-mouse monoclonal antibodies (Amersham) as required and developed with an enhanced chemiluminescence detection system (Amersham).

\section{RNA extraction and Northern blot analysis}

Total cellular RNA was isolated with the TRIzol protocol (Life Technologies). RNA quantitation, el ectrophoresis, and transfer to nitrocellul ose were performed as described ( $Y$ ang et al. 1995), and blots were probed with a nick-translated ${ }^{32}$ P-labeled DN A fragment encompassing residues 87-501 of human TRAF2.

\section{Reporter gene analysis}

Six-well plates were seeded with 293 cells at a density of $5 \times 10^{5}$ cells per well in $2 \mathrm{ml}$ of medium, and triplicate wells were transfected with $50 \mathrm{ng}$ each of a кB-responsive luciferase reporter plasmid containing two canonical $\kappa B$ sites (Klug et al. 1994) and a $\beta$-gal actosi dase transfection efficiency control plasmid, together with $100 \mathrm{ng}$ of either the CD28-CD 30 or the $\Delta$ tail control plasmid, as indicated. Transfectants were maintained for $48 \mathrm{hr}$ and stimulated where indicated with recombinant human TNF- $\alpha$ (200 U/ml; Boehringer Mannheim) or a medium control for $10 \mathrm{hr}$. Cells were harvested and luciferase reporter gene activity assayed as described previously (Duckett et al. 1997). 


\section{Acknowledgments}

We thank R. Arch, R. Gedrich, M. Gilfillan, A. Minn, C. Rudin, and members of the Thompson lab for thoughtful discussions and critical review of the manuscript; R. Arch, C. Rudin, and J. Van Dongen for providing TRAF4 and TRAF5 cDNAs; $\mathrm{H}$. Singh for providing luciferase plasmids; and T. Lindsten for assistance with $\mathrm{N}$ orthern blots. This work was supported by research grant P01 DK49799 (to C.B.T.) from the N ational Institutes of Health. C.S.D. is a Special Fellow of the Leukemia Society of America.

The publication costs of this article were defrayed in part by payment of page charges. This article must therefore be hereby marked "advertisement" in accordance with 18 USC section 1734 solely to indicate this fact.

\section{References}

Aizawa, S., H. Nakano, T. Ishida, R. Horie, M. Nagai, K. Ito, H. Yagita, K. Okumura, J. Inoue, and T. Watanabe. 1997. Tumor necrosis factor receptor-associated factor (TRAF) 5 and TRAF2 are involved in CD30-mediated N F-кB activation. J. Biol. Chem. 272: 2042-2045.

Allison, J. and M.F. Krummel. 1995. The yin and yan of T cell costimulation. Science 270: 932-933.

Amakawa, R., A. Hakem, T.M. Kundig, T. Matsuyama, J.J.L. Simard, E. Timms, A. Wakeham, H.-W. Mittruecker, H. Griesser, H. Takimoto, R. Schmits, A. Shahinian, P.S. Ohashi, J.M. Penninger, and T.W. Mak. 1996. Impaired negative selection of T cells in Hodgkin's disease antigen CD30-deficient mice. Cell 84: 551-562.

Ansieau, S., I. Scheffrahn, G. M osialos, H. Brand, J. Duyster, K. Kaye, J. Harada, B. Dougall, G. Hübinger, E. Kieff, F. Hermann, A. Leutz, and H.-J. Gruss. 1996. Tumor necrosis factor receptor-associated factor (TRAF)-1, TRAF-2, and TRAF-3 interact in vivo with the CD30 cytoplasmic domain; TRAF-2 mediates CD30-induced nuclear factor kappa B activation. Proc. Natl. Acad. Sci. 93: 14053-14058.

Armitage, R.J. 1994. Tumor necrosis factor receptor superfamily members and their ligands. Curr. Opin. Immunol. 6: 407413.

Baker, S.J. and E.P. Reddy. 1996. Transducers of life and death: TNF receptor superfamily and associated proteins. Oncogene 12: 1-9.

Beg, A.A. and D. Baltimore. 1996. An essential role for N F-кB in preventing TN F- $\alpha$-induced cell death. Science 274: 782-784.

Beyaert, R. and W. Fiers. 1994. M olecular mechanisms of tumor necrosis factor-induced cytotoxicity. What we do understand and what we do not. FEBS Lett. 340: 9-16.

Biswas, P., C.A. Smith, D. Goletti, E.C. Hardy, R.W. Jackson, and A.S. Fauci. 1995. Cross-linking of CD30 induces HIV expression in chronically infected T cells. Immunity 2: 587596.

Bump, N.J., M. Hackett, M. Hugunin, S. Seshagiri, K. Brady, P. Chen, C. Ferenz, S. Franklin, T. Ghayur, P. Li, P. Licari, J. Mankovich, L. Shi, A.H. Greenberg, L.K. Miller, and W.W. Wong. 1995. Inhibition of ICE family proteases by baculovirus antiapoptotic protein p35. Science 269: 1885-1888.

Cao, Z., J. Xiong, M. Takeuchi, T. Kurama, and D.V. Goeddel. 1996. TRAF6 is a signal transducer for interleukin-1. Nature 383: 443-446.

Chen, Z., J. Hagler, V.J. Pal ombella, F. M elandri, D. Scherer, D. Ballard, and T. Maniatis. 1995. Signal-induced site-specific phosphorylation targets $І \kappa \mathrm{B} \alpha$ to the ubiquitin-proteasome pathway. Genes \& Dev. 9: 1586-1597.

Chen, Z., L. Parent, and T. Maniatis. 1996. Site-specific phosphorylation of $I_{\kappa} B \alpha$ by a novel ubiquitination-dependent protein kinase activity. Cell 84: 853-862.

Cheng, G. and D. Baltimore. 1996. TANK, a co-inducer with TRAF2 of TNF- and CD40L-mediated NF-kB activation. Genes \& Dev. 10: 963-973.

Chinnaiyan, A.M., K. O'Rourke, M. Tewari, and V.M. Dixit. 1995. FADD, a novel death domain-containing protein, interacts with the death domain of Fas and initiates apoptosis. Cell 81: 505-512.

Chinnaiyan, A.M., K. O'Rourke, G.-L. Yu, R.H. Lyons, M. Garg, D.R. Duan, L. Xing, R. Gentz, J. Ni, and V.M. Dixit. 1996. Signal transduction by DR3, a death domain-containing receptor related to TN FR-1 and CD95. Science 274: 990-992.

Choi, M.S., L.H. Boise, A.R. Gottschalk, J. Quintans, C.B. Thompson, and G.G. Klaus. 1995. The role of bcl- $x_{L}$ in CD 40-mediated rescue from anti- $\mu$-induced apoptosis. Eur. J. Immunol. 25: 1352-1357.

Clem, R.J., M . Fechheimer, and L.K. Miller. 1991. Prevention of apoptosis by a baculovirus gene during infection of insect cells. Science 254: 1388-1390.

Del Prete, G., M. De Carli, M.M. D'Elios, K.C. Daniel, F. Almerigogna, M. Alderson, C.A. Smith, E. Thomas, and S. Romagnani. 1995. CD30-mediated signaling promotes the development of human T hel per type 2-like cells. J. Exp. Med. 182: 1655-1661.

DiDonato, J.A., F. Mercurio, and M. Karin. 1995. Phophorylation of $I_{\kappa} B \alpha$ precedes but is not sufficient for its dissociation from N F-кB. Mol. Cell. Biol. 15: 1302-1311.

DiDonato, J., F. Mercurio, C. Rosette, J. Wu-Li, H. Suyang, S. Ghosh, and M. Karin. 1996. Mapping of the inducible $І_{\kappa} B$ phosphorylation sites that signal its ubiquitination and degradation. Mol. Cell. Biol. 16: 1295-1304.

Duckett, C.S., V.E. Nava, R.W. Gedrich, R.J. Clem, J.L. Van Dongen, M.C. Gilfillan, H. Shiels, J.M. Hardwick, and C.B. Thompson. 1996. A conserved family of cellular genes related to the baculovirus iap gene and encoding apoptosis inhibitors. EMBO J. 15: 2685-2694.

Duckett, C.S., R.W. Gedrich, M.C. Gilfillan, and C.B. Thompson. 1997. Induction of nuclear factor $\kappa B$ by the CD 30 receptor is mediated by TRAF1 and TRAF2. Mol. Cell. Biol. 17: 1535-1542.

Dürkop, H., U. Latza, M. Hummel, F. Eitel bach, B. Seed, and H. Stein. 1992. Molecular cloning and expression of a new member of the nerve growth factor receptor family that is characteristic for Hodgkin's disease. Cell 68: 421-427.

Ellis, T.M., P.E. Simms, D.J. Slivnick, H.-M. Jäck, and R.I. Fisher. 1993. CD30 is a signal-transducing molecule that defines a subset of human activated CD45RO ${ }^{+} \mathrm{T}$ cells. J. Immunol. 151: 2380-2389.

Falini, B., S. Pileri, G. Pizzolo, H. Dürkop, L. Flenghi, F. Stirpe, M.F. Martelli, and H. Stein. 1995. CD30 (Ki-1) molecule: A new cytokine receptor of the tumor necrosis factor receptor superfamily as a tool for diagnosis and immunotherapy. Blood 85: 1-14.

Foy, T.M., A. A ruffo, J. Bajorath, J.E. Buhlmann, and R.J. N oelle. 1996. Immune regulation by CD40 and its ligand gp39. Annu. Rev. Immunol. 14: 591-617.

Gagliardini, V., P.A. Fernandez, R.K. Lee, H.C. Drexler, R.J. Rotello, M.C. Fishman, and J. Yuan. 1994. Prevention of vertebrate neuronal death by the crmA gene. Science 263: 826828.

Gedrich, R.W., M.C. Gilfillan, C.S. Duckett, J.L. Van Dongen, and C.B. Thompson. 1996. CD30 contains two binding sites with different specificities for members of the TRAF family of signal transducing proteins. J. Biol. Chem. 271: 1285212858.

Grell, M., E. Douni, H. Wajant, M. Lohden, M. Clauss, B. M ax- 
einer, S. Georgopoulos, W. Lesslauer, G. Kollias, K. Pfizenmaier, and P. Scheurich. 1995. The transmembrane form of tumor necrosis factor is the prime activating ligand of the 80 kDa tumor necrosis factor receptor. Cell 83: 793-802.

Gruss, H.-J. and S.K. Dower. 1995. Tumor necrosis factor ligand superfamily: Involvement in the pathology of malignant Iymphomas. Blood 85: 3378-3404.

Hateboer, G., R.M. Kerkhoven, A. Shvarts, R. Bernards, and R.L. Beijersbergen. 1996. Degradation of E2F by the ubiquitinproteasome pathway: Regulation by retinoblastoma family proteins and adenovirus transforming proteins. Genes \& Dev. 10: 2960-2970.

Henkel, T., T. M achleidt, I. Alkal ay, M. Krönke, Y. Ben-N eriah, and P.A. Baeuerle. 1995. Rapid proteolysis of $I_{\kappa} B-\alpha$ is necessary for activation of transcription factor NF-kB. Nature 365: 182-185.

Hsu, H., J. Xiong, and D.V. Goeddel. 1995. The TNF receptor 1-associated protein TRADD signals cell death and N F-KB activation. Cell 81: 495-504.

Hsu, H., H.-B. Shu, M.-G. Pan, and D.V. Goeddel. 1996. TRADD-TRAF2 and TRADD-FADD interactions define two distinct TNF receptor 1 signal transduction pathways. Cell 84: 299-308.

Ishida, T., S.-I. Mizushima, S. Azuma, N. Kobayashi, T. Tojo, K. Suzuki, S. Aizawa, T. Watanabe, G. Mosialos, E. Kieff, T. Yamamoto, and J.-I. Inoue. 1996a. Identification of TRAF6, a novel tumor necrosis factor receptor-associated factor protein that mediates signaling from an amino-terminal domain of the CD40 cytoplasmic region. J. Biol. Chem. 271: 2874528748.

Ishida, T., T. Tojo, T. Aoki, N. Kobayashi, T. Ohishi, T. Watanabe, T. Yamamoto, and J.-I. Inoue. 1996b. TRAF5, a novel tumor necrosis factor receptor-associated factor family protein, mediates CD40 signaling. Proc. Natl. Acad. Sci. 93: 9437-9442.

Kitson, J., T. Raven, Y.-P. Jiang, D.V. Goeddel, K.M. Giles, K.-T. Pun, C.J. Grinham, R. Brown, and S.N. Farrow. 1996. A death-domain containing receptor that mediates apoptosis. Nature 384: 372-375.

Klug, C.A., S.J. Gerety, P.C. Shah, Y.-Y. Chen, N.R. Rice, N. Rosenberg, and H. Singh. 1994. The V-abl tyrosine kinase negatively regulates $\mathrm{NF}-\mathrm{k} \mathrm{B} / \mathrm{Rel}$ factors and blocks $\kappa$ gene transcription in pre-B lymphocytes. Genes \& Dev. 8: 678687.

Komiyama, T., C.A. Ray, D.J. Pickup, A.D. Howard, N.A. Thornberry, E.P. Peterson, and G. Salvesen. 1994. Inhibition of interleukin-1 beta converting enzyme by the cowpox virus serpin CrmA. An example of cross-class inhibition. J. Biol. Chem. 269: 19331-19337.

Krappmann, D., F.G. Wulczyn, and C. Scheidereit. 1996. Different mechanisms control signal-induced degradation and basal turnover of the N F-кB inhibitor $\mathrm{I}_{\kappa} \mathrm{B} \alpha$ in vivo. EMBO J. 15: 6716-6726.

Lee, S.Y., C.G. Park, and Y. Choi. 1996. T cell receptor-dependent cell death of $\mathrm{T}$ cell hybridomas mediated by the CD30 cytoplasmic domain in association with tumor necrosis factor receptor-associated factors. J. Exp. Med. 183: 669-674.

Lee, S.Y., S.Y. Lee, and Y. Choi. 1997. TRAF-interacting protein (TRIP): A novel component of the tumor necrosis factor re ceptor (TNFR)- and CD30-TRAF signaling complexes that inhibits TRAF2-mediated NF-kB activation. J. Exp. Med. 185: $1275-1285$.

Liston, P., N. Roy, K. Tamai, C. Lefebvre, S. Baird, G. ChertonHorvat, R. Farahani, M. M cLean, J.-E. Ikeda, A. MacKenzie, and R.G. Korneluk. 1996. Suppression of apoptosis in mammalian cells by NAIP and a related family of IAP genes.
Nature 379: 349-353.

Liu, Z.G., H. Hsu, D.V. Goeddel, and M. Karin. 1996. Dissection of TNF receptor 1 effector functions: JNK activation is not linked to apoptosis, while NF-kB activation prevents cell death. Cell 87: 565-576.

Maggi, E., F. Annunziato, R. M anetti, R. Biagiotti, M.G. Giudizi, A. Ravina, F. Almerigogna, N. Boiani, M. Alderson, and S. Romagnani. 1995. Activation of HIV expression by CD30 triggering in $\mathrm{CD}^{+}$cells from HIV-infected individuals. Immunity 3: 251-255.

Malinin, N.L., M.P. Boldin, A. Kovalenko, and D. Wallach. 1997. M AP3K-related kinase involved in N F-кB induction by TNF, CD95 and IL-1. Nature 385: 540-544.

Marsters, S.A., J.P. Sheridan, C.J. Donahue, R.M. Pitti, C.L. Gray, A.D. Goddard, K.D. Bauer, and A. Ashkenazi. 1996. A po-3, a new member of the tumor necrosis factor receptor family, contains a death domain and activates apoptosis and N F-кB. Curr. Biol. 6: 1669-1676.

N adali, G., F. Vinante, H. Stein, G. Todeschini, C. Tecchio, L. Morosato, M. Chilosi, F. Menestrina, M.C. Kinney, J.P. Greer, U. Latza, G. Perona, and G. Pizzolo. 1995. Serum levels of the soluble form of CD30 molecule as a tumor marker in $\mathrm{CD} 30^{+}$anaplastic large-cell Iymphoma. J. Clin. Oncol. 13: 1355-1360.

N agata, S. 1996. A poptosis: Telling cells their time is up. Curr. Biol. 6: 1241-1243.

Nakano, H., H. Oshima, W. Chung, L. Williams-A bbott, C.F. Ware, H. Yagita, and K. Okumura. 1996. TRAF5, an activator of NF-кB and putative signal transducer for the lymphotoxin- $\beta$ receptor. J. Biol. Chem. 271: 14661-14664.

Natoli, G., A. Costanzo, A. Ianni, D.J. Templeton, J.R. Woodgett, C. Balsano, and M. Levrero. 1997. Activation of SAPK/JNK by TNF receptor 1 through a noncytotoxic TRAF2-dependent pathway. Science 275: 200-203.

Oltvai, Z.N. and S.J. Korsmeyer. 1994. Checkpoints of dueling dimers foil death wishes. Cell 79: 189-192.

Palombella, V.J., O.J. Rando, A.L. Goldberg, and T. Maniatis. 1994. The ubiquitin-proteasome pathway is required for processing the NF-kB1 precursor protein and the activation of NF-кB. Cell 78: 773-785.

Pan, G., K. O'Rourke, A.M. Chinnaiyan, R. Gentz, R. Ebner, J. $\mathrm{Ni}$, and V.M. Dixit. 1997. The receptor for the cytotoxic ligand TRAIL. Science 276: 111-113.

Rathmell, J.C., S.E. Townsend, J.C. Xu, R.A. Flavell, and C.C. Goodnow. 1996. Expansion or elimination of B cells in vivo: Dual roles for CD40- and Fas (CD95)-ligands modulated by the B cell antigen receptor. Cell 87: 319-329.

Rothe, M., S.C. Wong, W.J. Henzel, and D.V. Goeddel. 1994. A novel family of putative signal transducers associated with the cytopl asmic domain of the $75 \mathrm{kD}$ a tumor necrosis factor receptor. Cell 78: 681-692.

Rothe, M., M.-G. Pan, W.J. Henzel, T.M . Ayres, and D.V. Goeddel. 1995a. The TNFR2-TRAF signaling complex contains two novel proteins related to baculoviral inhibitor of apoptosis proteins. Cell 83: 1243-1252.

Rothe, M., V. Sarma, V.M. Dixit, and D.V. Goeddel. 1995b. TRAF2-mediated activation of N F-кB by TNF receptor 2 and CD40. Science 269: 1424-1427.

Rothe, M., J. Xiong, H.-B. Shu, K. Williamson, A. Goddard, and D.V. Goeddel. 1996. I-TRAF is a novel TRAF-interacting protein that regulates TRAF-mediated signal transduction. Proc. Natl. Acad. Sci. 93: 8241-8246.

Schwab, U., H. Stein, J. Gerdes, H. Lemke, H. Kirchner, M. Schaadt, and V. Diehl. 1982. Production of a monoclonal antibody specific for Hodgkin and Sternberg-Reed cells of Hodgkin's disease and a subset of normal Iymhoid cells. Na- 
ture 299: 65-67.

Siebenlist, U., G. Franzoso, and K. Brown. 1994. Structure, reguIation and function of N F-кB. Annu. Rev. Cell Biol. 10: 405455.

Smith, C.A., H.J. Gruss, T. Davis, D. Anderson, T. Farrah, E. Baker, G.R. Sutherland, C.I. Brannan, N.G. Copel and, N.A. Jenkins, K.H. Grabstein, B. Gliniak, I.B. McAlister, W. Fanslow, M. Alderson, B. Falk, S. Gimpel, S. Gillis, W.S. Din, R.G. Goodwin, and R.J. Armitage. 1993. CD30 antigen, a marker for Hodgkin's lymphoma, is a receptor whose ligand defines an emerging family of cytokines with homology to TNF. Cell 73: 1349-1360.

Song, H.Y., M. Rothe, and D.V. Goeddel. 1996. The tumor ne crosis factor-inducible zinc finger protein A20 interacts with TRAF1/TRAF2 and inhibits NF-кB activation. Proc. Natl. Acad. Sci. 93: 6721-6725.

Speiser, D.E., S.Y. Lee, B. Wong, J. Arron, A. Santana, Y.-Y. Kong, P.S. Ohashi, and Y. Choi. 1997. A regulatory role for TRAF1 in antigen-induced apoptosis of T cells. J. Exp. Med. 185: 1777-1783.

Squier, M.K. and J.J. Cohen. 1997. Calpain, an upstream regulator of thymocyte apoptosis. J. Immunol. 158: 3690-3697.

Stanger, B.Z., P. Leder, T.H. Lee, E. Kim, and B. Seed. 1995. RIP: A novel protein containing a death domain that interacts with Fas/APO-1 (CD95) in yeast and causes cell death. Cell 81: 513-523.

Stein, H., J. Gerdes, H. Lemke, and D.Y. M ason. 1985a. Evidence of Sternberg-Reed cells being derived from activated lymphocytes. In Modern trends in human leukemia VI (ed. R.C. Gallo, R. Neth, M.F. Greaves, and G. Janka), pp. 441-444. Springer-Verlag, Hei del berg, Germany.

Stein, H., D.Y. M ason, J. Gerdes, N. O'Connor, J. Wainscoat, G. Pallesen, K. Gatter, B. Falini, G. Delsol, H. Lemke, R. Schwarting, and K. Lennert. 1985b. The expression of the Hodgkin's disease associated antigen $\mathrm{Ki}-\mathrm{l}$ in reactive and neoplastic Iymphoid tissue: Evidence that Reed-Sternberg cells and histiocytic mal ignancies are derived from activated lymphoid cells. Blood 66: 848-858.

Takahashi, T., M. Tanaka, C.I. Brannan, N.A. Jenkins, N.G. Copeland, T. Suda, and S. N agata. 1994. Generalized Iymphoproliferative disease in mice caused by a point mutation in Fas ligand. Cell 76: 969-976.

Tartaglia, L.A., T.M. Ayres, G.H. Wong, and D.V. Goeddel. 1993. A novel domain within the $55 \mathrm{kdTN} F$ receptor signals cell death. Cell 74: 845-853.

Tartaglia, L.A., D.V. Goeddel, C. Reynolds, I.S. Figari, R.F. We ber, B.M. Fendly, and M.A. Palladino, Jr. 1993. Stimulation of human T-cell proliferation by specific activation of the 75-kDa tumor necrosis factor receptor. J. Immunol. 151: 4637-4641.

Tartaglia, L.A., D. Pennica, and D.V. Goeddel. 1993. Ligand passing: The 75-kDa tumor necrosis factor (TNF) receptor recruits TNF for signaling by the 55-kDa TNF receptor. J. Biol. Chem. 268: 18542-18548.

Tomasetto, C., C.H. Régnier, C. Moog-Lutz, M .G. Mattei, M.P. Chenard, R. Lidereau, P. Basset, and M.C. Rio. 1995. Identification of four novel human genes amplified and overexpressed in breast carcinoma and localized to the q11-q21.3 region of chromosome 17. Genomics 28: 367-376.

Tsitsikov, E., D.A. Wright, and R.S. Geha. 1997. CD30 induction of human immunodeficiency virus gene transcription is mediated by TRAF2. Proc. N atl. Acad. Sci. 94: 1390-1395.

Uren, A., M. Pakusch, C. Hawkins, K.L. Puls, and D.L. Vaux. 1996. Cloning and expression of apoptosis inhibitory proteins homologs that function to inhibit apoptosis and/or bind tumor necrosis factor receptor-associated factors. Proc.
Natl. Acad. Sci. 93: 4974-4978.

Van Antwerp, D.J., S.J. Martin, T. Kafri, D. Green, and I.M. Verma. 1996. Suppression of TNF- $\alpha$-induced apoptosis by N F-кB. Science 274: 787-789.

Vassalli, P. 1992. The pathophysiology of tumor necrosis factors. Annu. Rev. Immunol. 10: 411-452.

Wang, C.-Y., M.W. Mayo, and A.S.J. Baldwin. 1996. TNF- and cancer therapy-induced apoptosis: Potentiation by inhibition of NF-кB. Science 274: 784-787.

Weiss, A. and D.R. Littman. 1994. Signal transduction by lymphocyte antigen receptors. Cell 76: 263-274.

Weiss, T., M. Grell, B. Hessabi, S. Bourteele, G. Müller, P. Scheurich, and H. Wajant. 1997. Enhancement of TNF receptor p60-mediated cytotoxicity by TNF receptor p80. J. Immunol. 158: 2398-2404.

Xu, Y., G. Cheng, and D. Baltimore. 1996. Targeted disruption of TRAF3 leads to postnatal lethal ity and defective T-dependent immune responses. Immunity 5: 407-415.

Yang, H., C.S. Duckett, and T. Lindsten. 1995. iPABP, an inducible poly(A)-binding protein detected in activated human T cells. Mol. Cell. Biol. 15: 6770-6776.

Zheng, L., G. Fisher, R.E. Miller, J. Peschon, D.H. Lynch, and M.J. Lenardo. 1995. Induction of apoptosis in mature T cells by tumour necrosis factor. Nature 377: 348-351. 


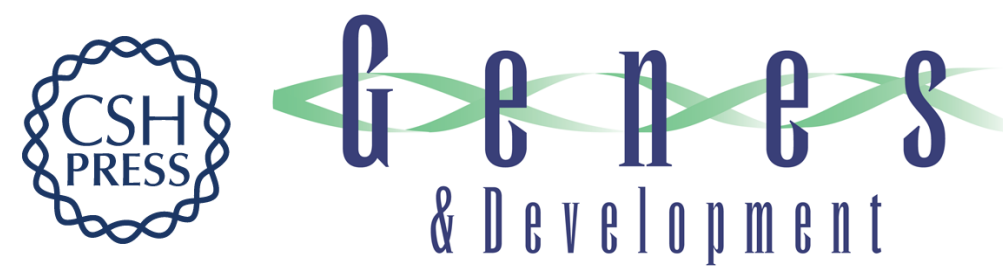

\section{CD30-dependent degradation of TRAF2: implications for negative regulation of TRAF signaling and the control of cell survival}

Colin S. Duckett and Craig B. Thompson

Genes Dev. 1997, 11:

Access the most recent version at doi:10.1101/gad.11.21.2810

$\begin{array}{ll}\text { References } & \begin{array}{l}\text { This article cites } 82 \text { articles, } 43 \text { of which can be accessed free at: } \\ \text { http://genesdev.cshlp.org/content/11/21/2810.full.html\#ref-list-1 }\end{array}\end{array}$

License

Email Alerting Receive free email alerts when new articles cite this article - sign up in the box at the top Service right corner of the article or click here.

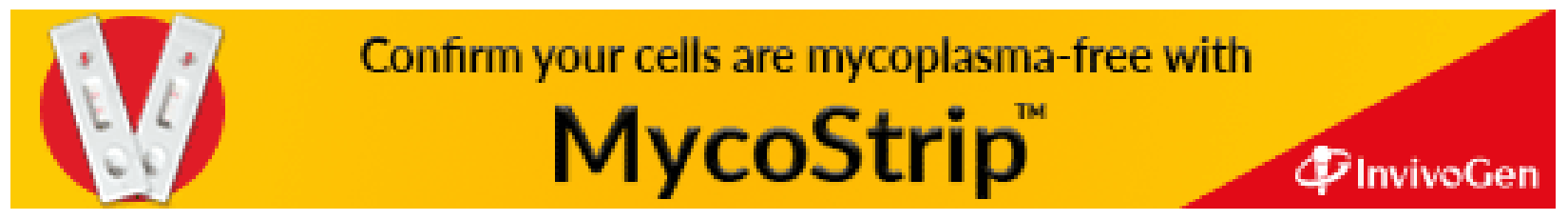

